\title{
Media Video Pembelajaran Teknik Dasar Bermain Bola Voli Pada Pelajaran Penjaskes
}

\author{
I Wayan Yoga Aryanata1 ${ }^{*}$, I Nyoman Jampel ${ }^{2}$, Luh Putu Putrini Mahadewi ${ }^{3}$
}

123 Jurusan Teknologi Pendidikan Universitas Pendidikan Ganesha

\begin{abstract}
Abstrak
Penelitian ini bertujuan untuk: mengembangkan media video pembelajaran teknik dasar bermain bola voli; menganalisis validitas hasil pengembangan media video pembelajaran teknik dasar bermain bola voli; serta menganalisis efektifitas pengunaan media video pembelajaran teknik dasar bermain bola voli terhadap hasil belajar siswa kelas X. Model pengembangan yang digunakan adalah model Hannafin and Peck. Metode pengumpulan data yaitu pencatatan dokumen, kuisioner, dan test. Teknik analisis data yang digunakan yaitu deskriptif kualitatif dan statistik inferensial. Hasil penelitian yaitu: rancang bangun dari media video pembelajaran dengan model Hannafin and Peck, media video pembelajaran yang dikembangkan valid dengan: (a) hasil review ahli isi sebesar 94\% (b) hasil review ahli desain pembelajaran sebesar $92 \%$, (c) hasil review dari ahli media sebesar $80 \%$, (d) hasil uji perorangan sebesar $96,6 \%$, (e) hasil uji kelompok kecil $85,1 \%$, hasil uji lapangan $94,1 \%$. (3) Efektifitas pengembangan menunjukan bahwa dengan thitung $>$ tabel sehinga $\mathrm{H}_{1}$ diterima yang menyatakan terdapat perbedaan yang signifikan hasil belajar Penjaskes siswa antara sebelum dan sesudah menggunakan media video pembelajaran. Dengan demikian video pembelajaran efektif digunakan untuk membantu proses pembelajaran Penjaskes siswa kelas X.
\end{abstract}

Kata Kunci:

Pengembangan, video pembelajaran, penjaskes.

\begin{abstract}
Tujuan This research aims to: develop video media for learning basic techniques for playing volleyball; analyze the validity of the results of the development of video media for learning basic techniques of playing volleyball; and analyze the effectiveness of the use of video media for learning basic techniques of playing volleyball on the learning outcomes of class X students. The development model used is the Hannafin and Peck model. Data collection methods are document recording, questionnaires, and tests. The data analysis technique used is descriptive qualitative and inferential statistics. The results of the study are: the design of learning video media using Hannafin and Peck models, the learning video media developed are valid with: (a) the results of expert content review by $94 \%$ (b) the results of learning design expert reviews by $92 \%$, (c) results review from media experts by $80 \%$, (d) individual test results by $96.6 \%$, (e) small group test results by $85.1 \%$, field test results by $94.1 \%$. (3) The effectiveness of the development shows that with tcount> ttable so that $\mathrm{H} 1$ is accepted stating that there are significant differences in student health learning outcomes between before and after using instructional video media. Thus the effective learning video is used to help the Physical Education learning process of class X students..
\end{abstract}

\section{Keywords:}

Development, learning videos, physical education 


\section{PENDAHULUAN}

Pendidikan merupakan sebuah sistem. Sebagai sistem, aktivitas pendidikan terbangun dalam beberapa komponen, yaitu pendidik, peserta didik, tujuan pendidikan, alat pendidikan, dan lingkungan pendidikan. Semua komponen yang membangun sistem pendidikan, saling berhubungan, saling tergantung, dan saling menentukan satu sama lain. Setiap komponen memiliki fungsi masing-masing dalam rangka mencapai tujuan pendidikan. Aktivitas pendidikan akan terselenggara dengan baik apabila didukung oleh komponen-komponen dimaksud. Fungsi pendidikan sebenarnya adalah menyediakan fasilitas yang dapat memungkinkan tugas pendidikan dapat berjalan lancar, baik secara struktural, maupun secara institusional. Secara struktural menuntut terwujudnya struktur organisasi yang mengatur jalannya proses kependidikan. Secara institusional mengandung implikasi bahwa proses kependidikan yang terjadi dalam struktur organisasi itu dilembagakan untuk lebih menjamin proses pendidikan itu berjalan secara konsisten dan berkesinambungan mengikuti kebutuhan dan perkembangan manusia yang cenderung ke arah tingkat kemampuan yang optimal (Saat, 2015).

Keberhasilan belajar peserta didik dipengaruhi oleh beberapa faktor, dapat berasal dari diri peserta didik sendiri maupun dari guru sebagai pendidik. Faktor yang berasal dari guru di antaranya kemampuan dalam merancang pembelajaran yang mampu menumbuhkan motivasi belajar peserta didik, menciptakan suasana belajar yang menarik dan menyenangkan. Namun pada kenyataannya, peserta didik masih menganggap matematika sebagai mata pelajaran yang menakutkan sehingga susah untuk dipahami. Hal ini terjadi karena pendidik belum mampu mengemas pembelajaran matematika menjadi lebih menyenangkan yang mampu menarik perhatian peserta didik. Sehingga membuat prestasi belajar peserta didik tidak sesuai dengan yang diharapkan (Ayuwanti, 2016).

Belajar merupakan suatu proses yang kompleks yang terjadi pada diri setiap orang sepanjang hidupnya. Winkel (dalam Pramiti, 2014:5) mengatakan "belajar merupakan suatu aktivitas mental atau psikis yang berlangsung dalam interaksi aktif dengan lingkungan yang menghasilkan sejumlah perubahan dalam pemahaman, keterampilan dan sikap nilai". Belajar dipandang sebagai proses yang diarahkan kepada tujuan dan proses melalui berbagi pengalaman. Proses belajar itu terjadi karena adanya interaksi antara seseorang dan lingkunganya. Oleh karena itu, belajar dapat terjadi kapan saja dan dimana saja. Keberhasilan pembelajaran tidak lepas dari cara mengajar pendidik dan cara perserta didik.

Pembelajaran dikatakan berhasil apabila adanya perubahan perilaku pada peserta didik ke arah yang lebih dapat dilihat dari segi pengetahuan, sikap, dan keterampilan yang di miliki oleh peserta didik. Pengajar memiliki tugas untuk mengarahkan dan membantu siswa agar dapat berkembang secara optimal sesuai dengan bakatnya. Pengajar harus mampu menciptakan suasana belajar yang kondusif sehingga memberikan suasana belajar yang nyaman, menyenakan, dan menarik. Suasana belajar yang efektif dapat membantu siswa dalam belajar, sehingga mampu mengembangkan diri secara optimal (Daryanto, 2011).

Dalam mengembangkan media yang kreatif dan inovatif, diperlukan teknolog pembelajaran. Merrill (dalam (Mahadewi, 2012:3) mengatakan bahwa "Teknologi Pendidikan tidak hanya mengacu pada alatalat (hardware) atau program aplikasi (software) yang digunakan dalam proses pembelajaran, tetapi mencangkup hal yang lebih luas lagi seperti pembelajaran, strategi pembelajaran, prinsip-prinsip dan teori pembelajaran". Berdasarkan hal tersebut maka dalam menciptakan pembelajaran yang efektif diperlukan sebuah strategi dan media pembelajaran yang sesuai guna mendukung pembelajaran, sehingga tujuan pembelajaran dapat tercapai.

Salah satu mata pelajaran yang memerlukan peran Teknologi Pendidikan adalah mata pelajaran pendidikan jasmani dan kesehatan (penjaskes). Penjaskes merupakan mata pelajaran yang menggunakan konsep pembelajaran learning by moving (belajar melalui gerak) (Suherman, 2004). Siswa sering melupakan instruksi dan gerakan yang berhubungan dengan materi pembelajaran, sehingga siswa akan kesulitan dalam belajar dan akan berdampak pada hasil belajar yang kurang maksimal. Hal ini terjadi pada siswa kelas X di SMA PGRI 4 Denpasar.

Berdasarkan hasil observasi dan wawancara dengan guru kelas X (Ibu Komang Thresia Fernawati ,S.Pd) yang dilakukan di SMA PGRI 4 Denpasar pada tanggal 13 Febuari 2019 ditemukan beberapa permasalahan yaitu: (1) metode ceramah masih dominan dalam proses pembelajaran, (2) praktek, tugas dan dalam proses pembelajaran hanya mengunakan buku LKS, (3) sumber materi hanya mengunakan buku LKS, (4) pada saat guru mata pelajaran Penjaskes tidak bertugas di sekolah atau izin karena alasan tertentu siswa cenderung ditugaskan untuk membersihkan halaman sekolah, sehabis itu siswa bermain diluar kelas menunggu bel istirahat berbunyi,dan (4) rendahnya hasil belajar siswa.

Berdasarkan permasalahan yang ditemukan, maka solusi yang dapat ditawarkan adalah pengembangan media video pembelajaran yang akan membantu siswa dalam belajar. Dengan media pembelajaran maka guru akan dimudahkan dalam menyampaikan materi, dan siswa lebih termotivasi dalam belajar. 
Agung (2012:12) menyatakan "hasil pembelajaran atau pelatihan dapat dipengaruhi oleh faktor raw input (pengetahuan awal, kemampuan peserta didik, dan lain-lain), instrumental input (kurikulum, media pembelajaran) serta faktor environmental input dan proses belajar mengajar/pelatihan". Berdasarkan hal tersebut maka dapat disimpulkan bahwa terdapat banyak faktor menentukan hasil belajar siswa dan salah satunya media pembelajaran yang akan membantu siswa dalam belajar.

Penggunaan media video Pembelajaran sangat menguntungkan, dengan fungsi media pembelajaran yaitu fungsi fikasatif, menurut Gerlach dan Ely dalam Ibrahim, et.al ( dalam Daryanto, 2012:8) fungsi fikasif yang berkaitan dengan kemampuan menangkap, menyimpan, dan kembali menampilkan suatu objek atau kejadian yang telah di rekam.

Riyana (2017:2) menyatakan "media video pembelajaran adalah media yang menyajikan audio dan visual yang berisikan pesan-pesan pembelajaran baik yang berisi konsep dan teori pembelajaran untuk membantu pemahaman siswa terhadap suatu materi pembelajaran".

Sehingga media video pemembelajaran akan sangat memudahkan siswa dalam memahami materi yang diberikan oleh guru, ini sejalan dengan pendapat dari (Mawarni,dkk, 2015) yang menyatakan media berfungsi untuk memperjelas, memudahkan, serta membuat sistem pembelajaran semakin menarik. Dengan pertimbangan di atas, maka perlu dikembangkan media video pembelajaran teknik dasar bola voli mata pelajaran penjaskes dengan menggunakan model Hannafin and peck.

\section{METODE PENELITIAN}

Model penelitian pengembangan yang digunakan sebagai acuan dalam pengembangan video pembelajaran teknik dasar bermain bola voli yaitu model pengembangan Hannafin and peck. Pemilihan model ini didasari atas pertimbangan bahwa model yang dikembangkan mengunakan sistem pembelajaran yang berorintasi produk (Tegeh dan Jampel, 2017). Model ini menekankan proses penilaian dan evaluasi yang mengikutsertakan proses dimana penilaian melibatkan tiga fase secara berkesinambungan yakni: (1) fase analisis, (2) fase perangcangan, (3) implementasi. Tahapan proses Hannafin and peck tersaji pada gambar berikut ini.

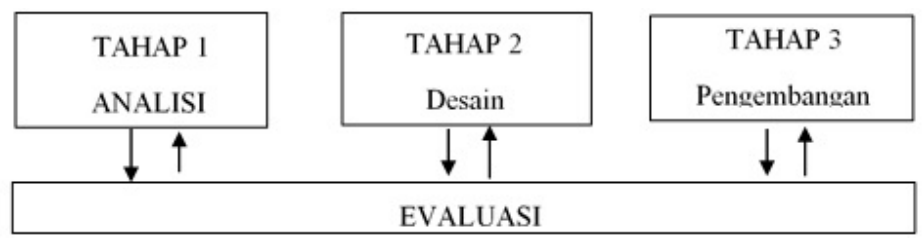

Gambar 1. Model Pengembangan Hannafid and Peck

Metode yang digunakan dalam penelitian ini yaitu: (1) metode kuesioner dan (2) metode tes. Metode kuisioner yang digunakan dalam penelitian ini adalah kuesioner tertutup (jawaban sudah disediakan dan responden hanya perlu memilih) dan kuesioner terbuka (responden bebas menuliskan komentar dan mengemukakan pendapat pada kuesioner) (Koyan, 2012). Kuesioner ini digunakan oleh uji dari ahli isi mata pelajaran, ahli desain pembelajaran, ahli media pembelajaran, dan uji coba siswa.

Metode tes yang digunakan dalam penelitian ini tes objektif. Tes objektif digunakan pada uji efektivitas hasil belajar siswa dengan melakukan pretes dan post tes (Suharsaputra, 2012). Instrumen yang digunakan dalam pengumpulan data pada penelitian ini yaitu: (1) kuesioner dan (2) test hasil belajar. Instrumen kuesioner ini digunakan pada tahap validasi yang meliputi uji coba para ahli dan uji coba siswa. Instrumen tes hasil belajar digunakan pada tahap uji efektivitas untuk mengetahui hasil belajar sebelum dan sesudah menggunakan media video pembelajaran.

Koyan (2011) menyatakan kuesioner merupakan sebuah daftar pertanyaan yang berbentuk kolom dan baris dan harus diisi dan harus diisi oleh responden (objek ukur). Agung (2012:16) juga menyatakan "metode kuesioner sebagai cara memperoleh atau menggumpulkan data dengan mengirimkan suatu daftar pertanyaan kepada responden atau subjek penelitian". Kuesioner digunakan untuk mengumpulkan data hasil review dari ahli isi bidang studi atau mata pelajaran, ahli desain pembelajaran dan ahli media pembelajaran, uji perorangan, uji kelompok kecil, dan uji lapangan. 


\section{ANALISIS DAN PEMBAHASAN}

Penelitian Uji normalitas data perlukan untuk memperlihatkan bahwa data sampel berasal dari populasi yang berdistribusi normal. Teknik yang digunakan pada uji normalitas adalah data liliefors dengan bantuan Microsoft excel. Hasil perhitungan yaitu sebagai berikut.

Tabel 2. Hasil Uji Normalitas Data

\begin{tabular}{|c|c|c|c|c|}
\hline No & Hasil belajar & Lhitung & $\mathrm{L}_{\text {tabel }}$ & Keterangan \\
\hline 1 & Pretest & 0.936 & 0.258 & Normal \\
\hline 2 & Posttest & 0.921 & 0.258 & Normal \\
\hline
\end{tabular}

Berdasarkan hasil perhitungan dengan menggunakan rumus liliefors, diperoleh $\mathrm{L}_{\text {hitung }}<\mathrm{L}_{\text {tabel }}$ dengan taraf signifikansi 5\%. Dengan demikian skor belajar pada mata pelajaran penjaskes siswa berdistribusi normal.

Setelah melakukan uji normalitas, kemudian dilakukan uji homogenitas dengan tujuan untuk memperlihatkan bahwa dua atau lebih kelompok data sampel berasal dari satu populasi yang sama homogenitas dihitung dengan bantuan mricrosof excel. Hasil perhitungan didapatkan variasi post-test 76.86 dan varisi pretest 701.01 sehingga untuk menguji homogenitas variasi data sampel digunakan uji $\mathrm{F}$. Berdasarkan hasil perhitungan, maka dapat disimpulkan bahwa $F_{\text {hitung }}(1,096)$ lebi kecil dari $F_{\text {tabel }}(5,76)$, sehingga $\mathrm{H}_{1}$ ditolak yang berati sampel bersifat homogen.

Setelah melakukan uji normalitas dan homogenitas maka selanjutnya dilakukan uji hipotesis dengan mengunakan rumus polled varians. $\mathrm{H}_{1}$ pada penelitian ini yaitu terdapat perbedaan yang signifikan hasil belajar penjaskes antara sebelum dan sesudah mengunakan media video pembelajaran. $\mathrm{H}_{\mathrm{o}}$ dari penelitian yaitu tidak terdapat perbedaan yang signifikan pada hasil belajar penjaskes sebelum dan sesudah menerapkan media video pembelajaran teknik dasar bermain bola voli pada.

Pengujian hipotesis dengan menggunakan analisis uji-t dengan sampel berkorelasi pada taraf signifikansi 5\% kriteria pengujian adalah apabila hasil penghitungan diperoleh nilai $t_{\text {tabel }}>t_{\text {hitung }}$ maka $\mathrm{H}_{0}$ ditolak dan $\mathrm{H}_{1}$ diterima. Berdasarkan hasil perhitungan, didapatkan bahwa $t_{\text {hitung }}$ lebih besar daripada $t_{\text {tabell }}$ sehingga dapat disimpulkan terdapat perbedaan yang signifikan pada hasil belajar penjaskes sebelum dan sesudah menggunakan media video pembelajaran di SMA PGRI 4 Denpasar.

Dalam penelitian pengembangan ini, produk yang dihasilkan adalah pengembangan media video pembelajaran teknik dasar permaian bola voli ini dikembangkan untuk mengatasi permasalahan pembelajaran penjaskes. Masalah tersebut adalah rendahnya hasil belajar siswa. Karena sangat sulit mempraktikan teknik dasar bola voli dengan pembelajaran yang monoton, sehinga diperlukan inovasi pembelajaran dengan dikembangkannya pengembangan media video pembelajaran.

Media video pembelajaran ini sudah mengalami proses uji dan perbaikan-perbaikan. Berikut ini akan disampaikan pembahasan hasil dari pengembangan media video pembelajaran dari hasil review dari ahli isi, ahli media, ahli desain pembelajaran, uji perorangan, uji kelompok kecil, uji lapangan dan pembahasan efektifitas media video pembelajaran ini dilakukan untuk menyempurnakan media video yang dibuat, sehingga media video pembelajaran ini mampu dan layak untuk digunakan dalam pembelajaran.

Hasil Validitas media video pembelajaran ini didapatkan berdasarkan hasil dari evaluasi dari para ahli yaitu meliputi: 1) ahli dari isi mata pelajaran, 2) ahli dari desain pembelajaran, 3) ahli media pembelajaran, sedangkan dari hasil evaluasi uji coba siswa yang meliputi: 4) uji perorangan 5) uji kelompok kecil, 6) uji lapangan. Adapun pembahasan dari uji validitas dari pengembangan media video pembelajaran teknik dasar bermain bola voli, sebagai berikut

Hasil review media video pembelajaran dari ahli isi mata pelajaran penjaskes diketahui bahwa mendapatkan hasil kualifikasi sangat baik dengan persentase $94 \%$, materi yang digunakan dalam media video pembelajaran sudah sesuai dengan tujuan pembelajaran dan kurikulum yang digunakan di SMA PGRI 4 Denpasar yang mengunakan kurikulum 2013. jika dilihat ulang dari aspek ahli isi mata pelajaran penjaskes, rancangan media video pembelajaran ini mendapatkan kualifikasi sangat baik dikarenakan sudah sesuai dengan RPP dan silabus yang digunakan, pada pembelajaran penjaskes. Kesesuaian isi dengan pandangan ahli isi mata pelajaran, dalam membuat media pembelajaran ini sangat sesuai dengan pendapat ahli isi bahwa dalam menilai aspek isi perlu memperhatikan keselarasan isi dengan tujuan pembelajaran, menurut Alenssi dan Trollip ( dalam frey, 2010:491). Pendapat ini sesuai dengan pendapat dari Munthe (2009:26) dalam desain pembelajaran yang digunakan dalam bahan ajar harus sesuai dengan 
desain materi, desain startegi pembelajaran yang digunakan dan desain evaluasi. Adapun beberapa unsur dari pengembangan tersebut harus saling berkaitan untuk menciptakan bahan ajar yang baik.

Penggunaan media video pembelajaran sebagai salah satu sumber belajar memberikan suatu pengalaman yang baru bagi siswa. Media video pembelajaran digunakan dalam proses belajar memiliki banyak manfaat dan keuntungan, diantara lain video merupakan pengganti teroi yang tidak bisa disampaikan oleh pengajar didalam kelas, karena terhalang kesibukan dan lain hal dan dapat mempermudah siswa untuk belajar materi pembelajaran dimanapun mereka inggin melakukan pembelajaran dan dapat juga diputar secara berulang-ulang. Video pembelajaran juga mendorong dan meningkatkan motivasi siswa untuk tetap melihat materi yang berada didalam video pembelajaran (Azhar Arsyad, 2011:49). Jadi siswa lebih praktis dan mudah untuk melakukan pembelajaran didalam kelas..

Berdasarkan hasil review dari ahli desain pembelajaran, diketahui bahwa mendapatkan hasil dengan kualifikasi sangat baik dengan persentase 92\% dan berada pada kualifikasi sangat baik. Menurut sudarma, dkk, (2015), ada beberapa faktor yang menyebabkan tercapainya validasi baik dari segi desain pembelajaran dan komponen pembelajaran sebagai berikut yaitu. Pertama, dikaji dari aspek perumusan tujuan pembelajaran, sudah dikembangkan berdasarkan kompetensi inti dan kompetensi dasar rumusan tujuan pembelajaran. Selanjutnya, diikuti oleh luasan cakupan materi sehingga rangkuman materi mampu mendukung tercapainya tujuan pembelajaran. Kesesuaian materi, metode penilaian sudah berdasarkan rumusan oprasional, indikator tujuan pembelajaran. Kedua, siswa yang menjadi sasaran menggunaan media video pembelajaran. Parmiti (2014) mengatakan bahwa peserta didik mempunyai karakter dan sikap prilaku berupa pengetahuan, ketrampilan. Pengembang perlu mengetahaui karakteristik dari siswa sehingga tujuan pembelajaran dapat terpenuhi dengan baik.

Berdasarkan hasil review dari ahli media pembelajaran video pembelajaran mendapatkan persentase $80 \%$ dengan kualifikasi baik dan kualitas video pembelajaran baik dikarenakan dalam setiap mengembangkan media pembelajaran harus pemperhatikan tampilan dari media pembelajaran itu sendiri. Hal tersebut penting untuk diperhatikan oleh pengembang media agar mempermudah siswa dalam memahami materi yang terkandung dalam media yang dikembangkan. Rusman (2012:22) menyatakan bahwa video pembelajaran dapat memberikan pesan yang dapat diterima lebih merata oleh siswa. Sejalan dengan teori Sudarma (2015:06) menyatakan video merupakan elemen yang mampu memberikan gambaran nyata dari sebuah kejadian atau peristiwa. Ini merupakan keungulan video pembelajaran. Sudarma (2015:18) menyatakan kemenarikan gambar dapat membangkitkan motivasi pembaca. Kemenarikan gambar itu tentu memiliki kaitan dengan pesan yang disampaikan dalam media tersebut. Agar pesan yang ingin disampaikan kepada siswa memiliki arti yang baik dan tidak membingungkan sisiwa dalam mengartikan pesan.

Berdasarkan uji coba perorangan yang diujikan coba kepada 3 orang siswa di SMA PGRI 4 Denpasar, media video pembelajaran mendapatkan persentase tingkat pencapaian sebesar $96,6 \%$ dengan kualifikasi sangat baik. Selanjutnya dilakukan uji kelompok kecil yang siswanya lebih banyak dari uji perorangan, siswa yang mengikuti uji kelompok kecil ini sebanyak 12 orang dari kelas XI MIA 1 SMA PGRI 4 Denpasar, dengan mendapatkan persentase tingkat pencapaian sebesar $85 \%$, dengan kualifikasi sangat baik, selanjutnya kembali dilakukan uji coba lapangan kali ini jumlah peserta didik lebih banyak dari uji perorangan dan uji kelompok kecil, uji lapangan ini mendapatkan persentase tingkat pencapaian sebesar 94\%, dengan kualifikasi sangat baik.

Dimana seluruh hasil uji coba tersebut mendapatkan kualifikasi sangat baik dan mendapatkan respon yang baik dari siswa dikarenakan beberapa hal yang ada di dalam media video pembelajaran ini membuat siswa tertarik untuk mempelajari teknik dasar bermain bola voli. Hal ini sejalan dengan pendapat dari Darwanto (2007:18) bahwa Media video pembelajaran merupakan media pembelajaran yang tepat untuk memperlihatkan contoh keterampilan bergerak atau psikomotor karena dapat diperjelas, atau diperlambat maupun dipercepat sesuai dengan kebutuhan peserta didik yang berada pada suatu lembaga pendidikan tertentu. Sejalan dengan pendapat ahli dari Arif S. Sadiman (2009:74) bahwa keunggulan mengunakan media video pembelajaran diantaranya, dapat menarik perhatian untuk periodeperiode yang sangat singkat dari rangsangan luar lainya, penonton atau siswa memperoleh informasi materi dari para ahlinya atau spesialis dalam bidangnya menghemat waktu pembelajaran di dalam kelas dan dapat memutar kembali video pembelajaran dimana pun dan kapanpun siswa itu ingin memutarnya, bisa mengamati objek yang sulit untuk dilihat secara perlahan, ruangan tidak perlu digelapkan pada saat menampilkan media video pembelajaran ini.

Berdasarkan hasil analisis data kuisioner dalam uji perorangan uji kelompok kecil dan uji lapangan yang disampaiakan diatas, dapat disimpulkan bahwa media video pembelajaran yang di kembangkan untuk pembelajaran penjaskes ini mendapatkan respon yang positif dari siswa di SMA PGRI 4 Denpasar. 


\section{KESIMPULAN}

Simpulan dari penelitian pengembangan yaitu (1) rancang bangun penelitian pengembangan ini mengunakan model Hannafin and peck yang terdiri dari tiga tahap analisis, tahap desain, dan tahap pengembangan dan implementasi, (2) validasi dari ahli isi mata pelajaran mendapatkan kualifikasi sangat baik, ahli desain Pembelajaran mendapatkan kualifikasi sangat baik, ahli media pembelajaran mendapatkan kualifikasi baik, uji coba perorangan mendapatkan kualitas sangat baik, uji coba kelompok kecil mendapatkan kualitas baik, dan uji lapangan dengan kualitas sangat baik. Jadi media video pembelajaran teknik dasar bermain bola voli telah dinyatakan valid. (3) hasil uji efektifitas dengan uji-t berdasarkan nilai pre-test dan post-test yaitu video pembelajaran teknik dasar bermain bola voli efektif diterapkan pada siswa kelas $\mathrm{x}$. Diharapkan siswa lebih terbantu dalam belajar dengan video pembelajaran. diharapkan guru dapat mengembangan media pembelajaran yang inovatif sehingga membantu siswa dalam belajar.

\section{DAFTAR PUSTAKA}

Agung, A. A (2012). Metodologi Penelitian Pendidikan. Singaraja: Undiksha.

Arief S. S (2009). Media Pendidikan. Jakarta: PT Raja Grafindo Persada.

Ayuwanti, Irma. 2016. Meningkatkan Aktivitas Dan Hasil Belajar Matematika Menggunakan Model Pembelajaran Kooperatif Tipe Group Investigation Di Smk Tuma'ninah Yasin Metro. Jurnal SAP Vol. 1 No. 2 Desember 2016.

Azhar, A. (2011) Media Pembelajaran. Jakarta: Rajawali Pers.

Daryanto. (2011). Media Pembelajaran. Jakarta: PT Raja Grafindo Persada.

Daryanto. (2012). Media Pembelajaran Bandung: PT. Sarana Tutorial Nurani Sejahtera.

Darwanto. (2007). Televisi sebagai Media Pendidikan. Pustaka Pelajar.

Frey, B. A., \& J. M. S. 2010. A Model for Developing Multimedia Learning Projects. Journal of Online Learning and Teaching, Volume (6), Nomor 2 (hlmn.491-507). Tersedia pada https://edcavasuploads.s3.amazonaws.com, (diakses pada tanggal 4 Febuari 2020.)

Koyan, I. W. (2011). Asesmen dalam Pendidikan. Singaraja: Undiksha.

Koyan, I W. (2012). Statistik Pendidikan: Teknik Analisis data Kuantitatif. Singaraja : Undiksha Press.

Mahadewi, D. (2012). Buku Ajar: Media Vedio Pembelajaran (E-Bokk). Singaraja: Undiksha.

Mawarni, E., Mulyani, B., \& Yatinah, S 2015: Penerapaan Peer toturing Dilengkapi Animasi Macromedia Flash dan Handout untuk Meningkatkan Motivasi Berprestasi dan Prestasi Belajar Peserta didik Kelas XI IPA 4 SMAN 6 Surakarta Tahun pelajaran 2013/2014 pada Materi Kelarutan dan Hasil Kelarutan. Jurnal Pendidikan kimia. 4(1):29-37. ( (diakses pada 12 Juli 2020).

Munthe, B. (2009). Desain Pembelajaran. Yogyakarta: Pustaka Insani Mandani.

Riyana, C. (2007). Pedoman pengembangan Media Video. Bandung: Universitas Pendidikan Indonesia.

Rusman. (2012), Belajar dan Pembelajaran Berbasis Komputer Mengembangkan Profesionalisme Guru Abad 21. Bandung: Alfabeta.

Saat, Sulaiman. 2015. Faktor-Faktor Determinan Dalam Pendidikan (Studi Tentang Makna Dan Kedudukannya Dalam Pendidikan). Jurnal Al-Ta'dib Vol. 8 No. 2, Juli-Desember 2015

Sudarma, I. K., \& dkk. 2015. Desain Pesan Kajian Analisis Visual Teks dan Image. Yogayakarta: Graha Ilmu. 
Suharsaputra, U. (2012). Metode penelitian Kuantitatif, Kualitatif, dan Tindakan. Bandung: PT Refika Aditama.

Suherman, A. (2004). Dasar-Dasar Penjaskes. Jakarta: Departemen Pendidikan Nasional.

Parmiti, D.P. 2014. Pengembangan Bahan Ajar. Singaraja :Undiksha.

Tegeh, I. M. \& dkk ( 2014). Model Penelitian Pengembangan. Yogyakarta : Graha Ilmu.

Tegeh dan Jampel (2017). Metode Penelitian P engembangan. Singaraja: Universitas Pendidikan Ganesha. 